\title{
FIRE HISTORY OF PATAGONIA: CLIMATE VERSUS HUMAN CAUSE
}

\author{
Vera MARKGRAF \\ Lysanna ANDERSON
}

\begin{abstract}
Human society's concern about future environmental changes in response to both natural forcings, such as climate, and ever increasing human impact can only be addressed if the interaction between the natural and man-made forcings are fully understood. One parameter that lends itself for such analysis is fire. The historical record is too short and ambiguous to provide data adequate to discriminate between natural and man-induced changes in fire frequencies. Paleoenvironmental records, inclusive of both the historic and the prehistoric past, can provide an appropriate data set with which to address this question. These data include paleoclimate reconstructions, pollen, and charcoal records from dated sediment sections, and information on past human impact derived from historical and archaeological evidence. The Patagonian region is well suited for such a study because of its climatic diversity, its wide range of ecosystems, and the adaptation of its ecosystems to fire. Records from latitudes $36^{\circ}$ to $55^{\circ} \mathrm{S}$ suggest that although prehistoric human activities may have amplified extent of fires, climate played the central role. Changes in patterns of climate variability were particularly important. Whenever variability was high, during the late glacial and the late Holocene, fires were abundant. Late glacial variability is probably related to fluctuations in the extent of Antarctic sea-ice which in turn influences the latitudinal position of the westerly stormtracks; late Holocene variability, on the other hand, is related to the influence of El Niño/Southern Oscillation.
\end{abstract}

\section{INTRODUCTION}

One of the biggest challenges in predicting future environmental response to ever increasing pressure from human impact is how the effects of natural driving forces (e.g. climate) interact with the effects of anthropogenic forcing. One parameter that lends itself to such analysis is fire. Fire is related to both climate and human activity. It also has a profound influence on environmental changes and ecosystem processes.

Changes in fire regime may have consequences that extend far beyond a local or regional ecosystem scale change. Marked changes in black carbon analyzed from the Antarctic Byrd ice core (CHYLEK et al., 1992) during the last 13000 years B.P. (Before Present) indicate that charcoal particles, although produced regionally, are redistributed globally. The black carbon component of aerosols originating from forest fires represents a feedback mechanism that influences climate on a global scale (SCHNEIDER, 1976).

The quintessential question is, if and to which degree human-induced fires interact or even irreversibly alter the environment in combination with, or independent of, concurrent climate-induced environmental change. To adequately address this question we need to know how different human activities, especially burning, affect different environments under different climate scenarios.

Most ecosystems in Patagonia, except the most permanently wet rainforests, are adapted to fires. Recent studies have led to a good understanding of the dynamics of vegetation response and adaptations to fire pressure (ERIKSEN, 1975; VEBLEN \& LORENZ, 1987; VEBLEN et al., 1992). This adaptation to fire suggests that for a given community, a constant fire regime is not a "disturbance", but an integral component of the ecosystem that contributes to the maintenance of that community (PICKETT et al., 1989). As such, it is not fire per se that may result in environmental change, but changes in fire frequency and/or intensity. The question of the degree and dimension of human impact, especially as it relates to future global change, can not be adequately addressed by historical records. Documented changes in fire regime and corresponding changes in character and magnitude of environmental response represent only a limited range of 
scenarios. Long-term records of changes in climate, fire history, and changing patterns of human occupation and land use may give us the broader picture needed to determine the relation between fire, man and the ecosystem.

Patagonia is particularly well suited for such a study due to 1) the diversity of climates and environments, 2) latitudinally distinct evolution of environmental change and 3) sensivity of the natural system to fire (MARKGRAF, 1993a, MARKGRAF et al., 1992; VEBLEN et al., 1992). Paleoenvironmental records from sites between latitudes $36^{\circ} \mathrm{S}$ and $55^{\circ} \mathrm{S}$ document a long and variable history of changes in climate and fire regime, extending back continuously to about 15000 years B.P. (HEUSSER, 1987; 1990; MARKGRAF, 1991a; MARKGRAF, 1993a). Archaeological and historical data throughout Patagonia document different phases of human occupation as far back as 13000 years B.P. (e.g. MASSONE, 1987; BIRD \& BIRD, 1978; LYNCH, 1983; MENA, 1991). This combination - present and past diversity of ecosystems and climates within and between each latitudinal band, and the correlative records of historic and prehistoric human occupation - represents a significant opportunity to assess the sensivity of distinct natural systems to natural and anthropogenic changes in fire frequency.

Thus, analysis of long-term changes in fire regime in Patagonia offers a unique opportunity to study interaction between climate and man. Analysis of records of paleoenvironmental change and paleo-fire events from the wide range of biota represented at these latitudinal segments will address the following specific aspects:

1) Sensitivity of different ecosystems, from temperate rainforests to Andean forests and steppe, to present and past natural and manmade fire disturbance and patterns of ecosystem recovery;

2) The effect of climate, past and present, from permanently wet to seasonally droughtaffected, and from temperate to cold conditions on the frequency, amplitude, and recurrence of fire disturbance; and

3) The influence of impacts from Paleoindian, colonial, and modern land-use patterns on fire frequency and its relationship to climate change.

In this paper we will discuss the available paleoenvironmental records as a means of differentiating among these influences on environmental change. First we will present a brief summary of current theory on the controls of fire/vegetation dynamics. Second we will review the data and the interpretations of the timing and nature of changes in climate regimes, fire regimes, and vegetation communities throughout southern South America. Finally, we will discuss these data in terms of their implications for differentiating between the influence of humans and climate on changes in fire regime and plant communities.

\section{BACKGROUND}

Controls on fire frequency and intensity Changes in fire regimes are the consequence of external triggers (e.g. climate, man) interacting with predisposing characteristics of each specific ecosystem (PICKETT et al., 1989). These characteristcs include fuel quantity and quality and its spatial distribution, vegetation community structure and patchiness, and local topography, including presence or absence of fire breaks (GRIMM, 1984; WRIGHT, 1981). Much paleoenvironmental research in North America has focused on defining the ecological constraints on fire frequencies. Analysis of periodicities of fires in Minnesota (CLARK, 1988; GRIMM, 1984), southern Ontario (CWYNAR, 1978) and the Canadian northern Territories (JOHNSON, 1979) showed fire frequency to be driven by climate, primarily recurrence of droughts, and regulated by the dynamics of fuel regime. With other words, every fire regime is related to the specific fuel regime of a given vegetation. This implies that under the same climatic conditions, fires will show periodicities representative of fuel availability increasing with time. In the North American hardwood forests fuel build-up reaches a maximum after about 150 to 300 years. To determine how a specific fire regime is maintained, or changed, what the specific forcings are, and how effects of different forcing might interact, it is necessary therefore to make use of long-term records of past change.

Pollen and charcoal as long-term records - Records of past fires are interpreted from changes in the abundance of charcoal in the same sediment sections analyzed for pollen. Combining pollen and charcoal data as proxy data for the interpretation of ecosystem dynamics assumes that the factors controlling the abundance of both charcoal and pollen present in the fossil record are similar. Most troublesome among these factors is source area, as defined by the dynamics of particle motion and deposition. Simply stated: if inferences about the nature of a community's response to fire are going to be derived from proxy evidence, then the source area for the proxies must be 1) similar, and 2) limited to that community. 
The dynamics of pollen and charcoal transport and deposition have been discussed extensively. CLARK (1988) has presented a model for deposition of charcoal particles of the size found on pollen slides that suggests source areas of up to several hundred kilometers distant. This is a much larger source area than has been presented for pollen. PRENTICE (1985), and JACOBSON \& BRADSHAW (1981) have developed models of pollen deposition in which basins of greater than $100 \mathrm{~m}$ diameter correspond to source areas of $20 \mathrm{~m}$ to $200 \mathrm{~km}$. The percentage of the pollen in the sediments derived from more distant source areas increases with increasing basin size. The difference in dispersal betweeen pollen and charcoal is due primarily to the effect on charcoal of the lifting ability of fires. Heat from fires can set up convection currents that may raise particulates much higher than normal boundary effects would loft pollen (CLARK, 1988).

Although these models suggest that the source areas for pollen and charcoal may be significantly different, a strong correlation has been shown between influx rates of local and regional pollen and pollen slide charcoal counts (GREEN et al., 1988; GREEN \& DOLMAN, 1988; DODSON, 1988; GREEN, 1983, Clark, personal communication). These empirical data support the assumption that pollen and charcoal do have similar patterns of transport and deposition, and that the fossil record in moderately size basins ( 100 to $300 \mathrm{~m}$ diameter) is dominated by a signal corresponding to a source area extending from several $100 \mathrm{~m}$ to a few kilometers.

The use of pollen and charcoal as proxies for vegetation/fire interaction - One of the regions best studied for effects of fire on biota, present and past, is Australia (GILL, 1975; GILL et al., 1981; GREEN \& DOLMAN, 1988; DODSON, 1988). There, evolution of distinctive fire adapted ecosystems during early Tertiary times has been ascribed to changes in fire regime related to climate change, specifically to the onset of seasonally variable precipitation (RECHER \& CHRISTENSEN, 1981; KEMP, 1981). During the more recent late Pleistocene period, further changes in forest composition and forest distribution reflecting increasing fire adaptation were found coeval with the peopling of Australia. At that point the changes were attributed solely to systematic burning by the aborigines (SINGH et al., 1981; KERSHAW, 1986). Not only was the role of climate considered far less important than man in altering the fire regime, but the altered vegetation itself was made responsible for irrever- sibly affecting climate such as the Australian monsoon (MILLER, 1992). The debate on relative importance of climate versus humans in changing fire regimes has continued, for Australasia (e.g. McGLONE et al., 1992) as well as for North America (e.g. PATTERSON \& SASSAMAN, 1988; CLARK, 1988; GRIMM, 1984) but to quantitatively differentiate either forcing's relative importance on the ecosystem has remained difficult.

One promising approach which may provide a means of distinguishing human and climatic influence is the use of time series analysis of high resolution pollen records to reconstruct vegetation dynamics within periods of relative environmental stability (GREEN \& DOLMAN, 1988; DODSON, 1988). These studies have focused on the dynamics of fuel build-up and fire intensity interpreted from relationships between influx of charcoal, inorganics, and specific pollen taxa. Time series analysis techniques were used to determine the periodicities and temporal correlations within and between these variations in influx. This innovative approach to pollen analysis has provided an important opportunity to observe the dynamics of ecological processes that occur on time scales longer, not only than an observer's life time, but longer than the life span of individual members of the community observed.

As yet Patagonia does not have the high resolution charcoal and pollen records necessary to support the use of this approach for quantitative analysis. It may, however, be possible to use the conceptual aspects of this approach to qualitatively interpret covariance patterns of community assemblage and fire frequency.

\subsection{Modern environments}

Southern South America exhibits a highly diverse complex of vegetation communities, as a result of a complex pattern of climatic diversity. Between latitudes $36^{\circ}$ and $55^{\circ} \mathrm{S}$ the principal climatic controls are 1) the westerly air masses, and 2) the orographic climate gradient produced by the Andes. Seasonal shifts in the belt of westerly stormtracks produce different seasonal patterns of precipitation at different latitudes. At lower latitudes precipitation occurs primarily in the winter. Precipitation at higher latitudes occurs year-round. Consequently, the lower latitudes are more likely to experience drought conditions in summer than the more southerly latitudes. On the other hand, drought is common east of the Andes at all latitudes due to the orographic precipitation gra- 


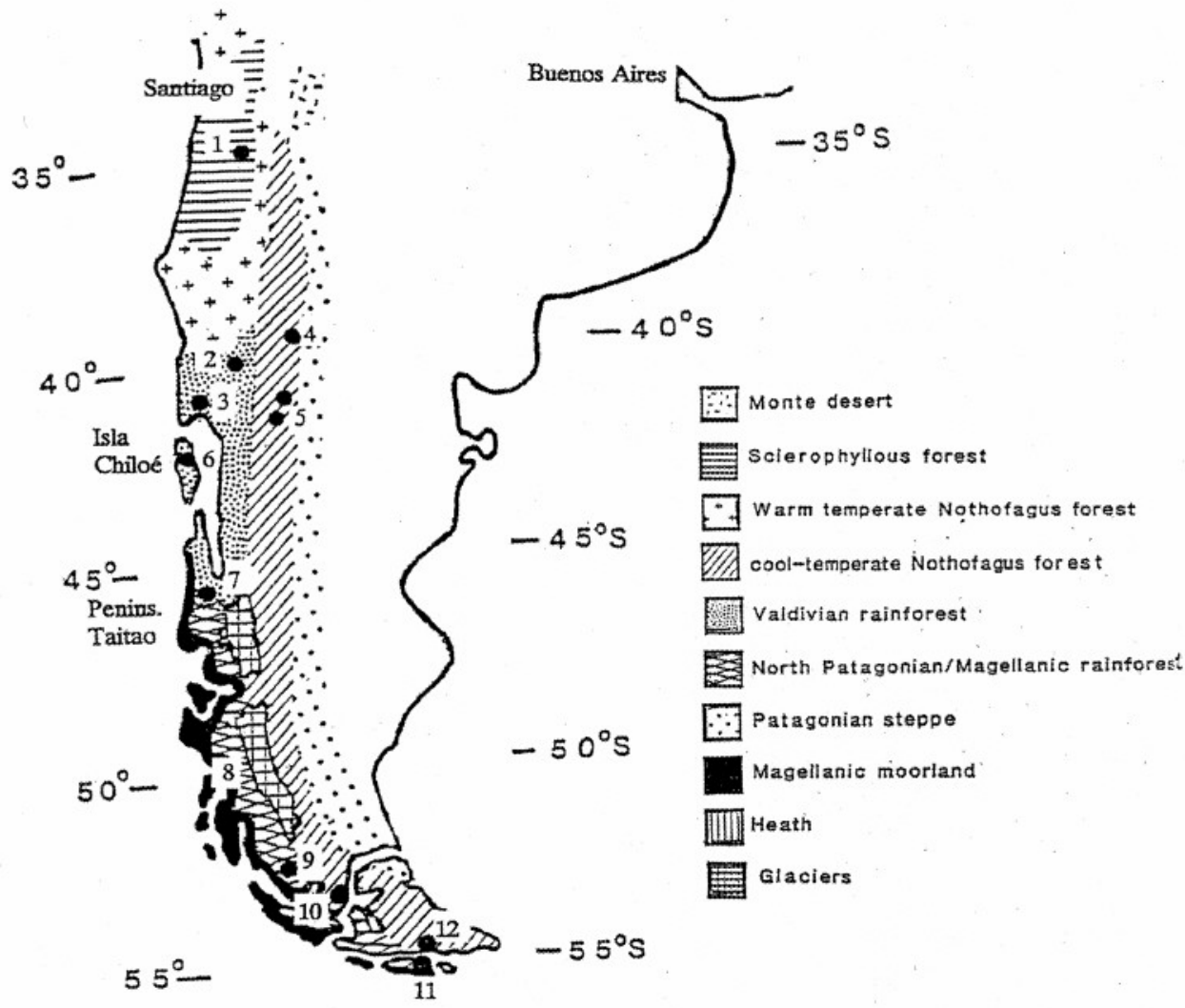

FIGURE 1 - Map of Patagonia with major vegetation types and sites mentioned in the text. 1: Tagua Tagua (HEUSSER, 1990); 2: Caunahue (MARKGRAF, 1991a); 3: Puerto Octay (MORENO, 1993); 4: Rio Malleo (HEUSSER et al., 1987); 5: Lago Morenito (MARKGRAF, 1984) and Mallin Book (MARKGRAF, 1983); 6: Rio Negro (VILLAGRAN, 1988); 7: Taitao Peninsula (LUMLEY \& SWITSUR, 1993); 8: Puerto Eden (ASHWORTH et al., 1991); 9: Torres del Paine (HEUSSER, 1987); 10: Puerto Hambre and Punta Arenas (HEUSSER, 1987); 11: Puerto Williams (HEUSSER, 1987); 12: Harberton (MARKGRAF, 1991b).

dient. Frontal storms with lightning activity have been documented to cause fires throughout the Andean forests, especially in the midlatitudes along the eastern foothills (VEBLEN \& LORENZ, 1987).

These west/east and north/south precipitation gradients are mirrored in the modern vegetation zonation and composition (figure 1). The most diverse forest ecosystems are found in the coastal ranges and lowlands west of the Andes at latitudes $36^{\circ}$ to $42^{\circ} \mathrm{S}$, represented by different warm-temperate and cool-temperate Nothofagus rainforests. Annual precipitation ranges between 2000 and $5000 \mathrm{~mm}$ and mean annual temperatures are above $8^{\circ} \mathrm{C}$. South of latitude $42^{\circ} \mathrm{S}$ and at higher elevations, less diverse deciduous Nothofagus forests replace the rainforests. Mean annual temperatures are less than $8^{\circ} \mathrm{C}$, but annual precipitation continues above $2000 \mathrm{~mm}$. Above treeline, where temperatures annually fall below $5^{\circ} \mathrm{C}$, Andean fellfield vegetation expands. Across the Andes to the east with annual precipi- tation decreasing below $1000 \mathrm{~mm}$ a dry Nothofagus/Austrocedrus forest and ultimately with less than $600 \mathrm{~mm}$ annual precipitation steppe and steppe-scrub vegetation expands.

\subsection{Paleoclimates}

Reconstruction of past climates throughout the southern latitudes has been based primarily on pollen records (figures 1 and 2) most of which date back continuously to at least 15000 years B.P. Prior to that time glaciers extended from the Andes far into the lowlands on either side of the mountains, creating basins that began to accumulate sediment after glaciers retreated. Only north of latitude $43^{\circ} \mathrm{S}$, where the ice-free area was extensive even to the west of the Andes, are there some records that extend back through the last full-glacial interval dated to about 18000 years B.P. (e.g. HEUSSER \& FLINT, 1977; VILLAGRAN, 1990).

It is important to note that although the timing of change has been synchronous, evolution of cli- 


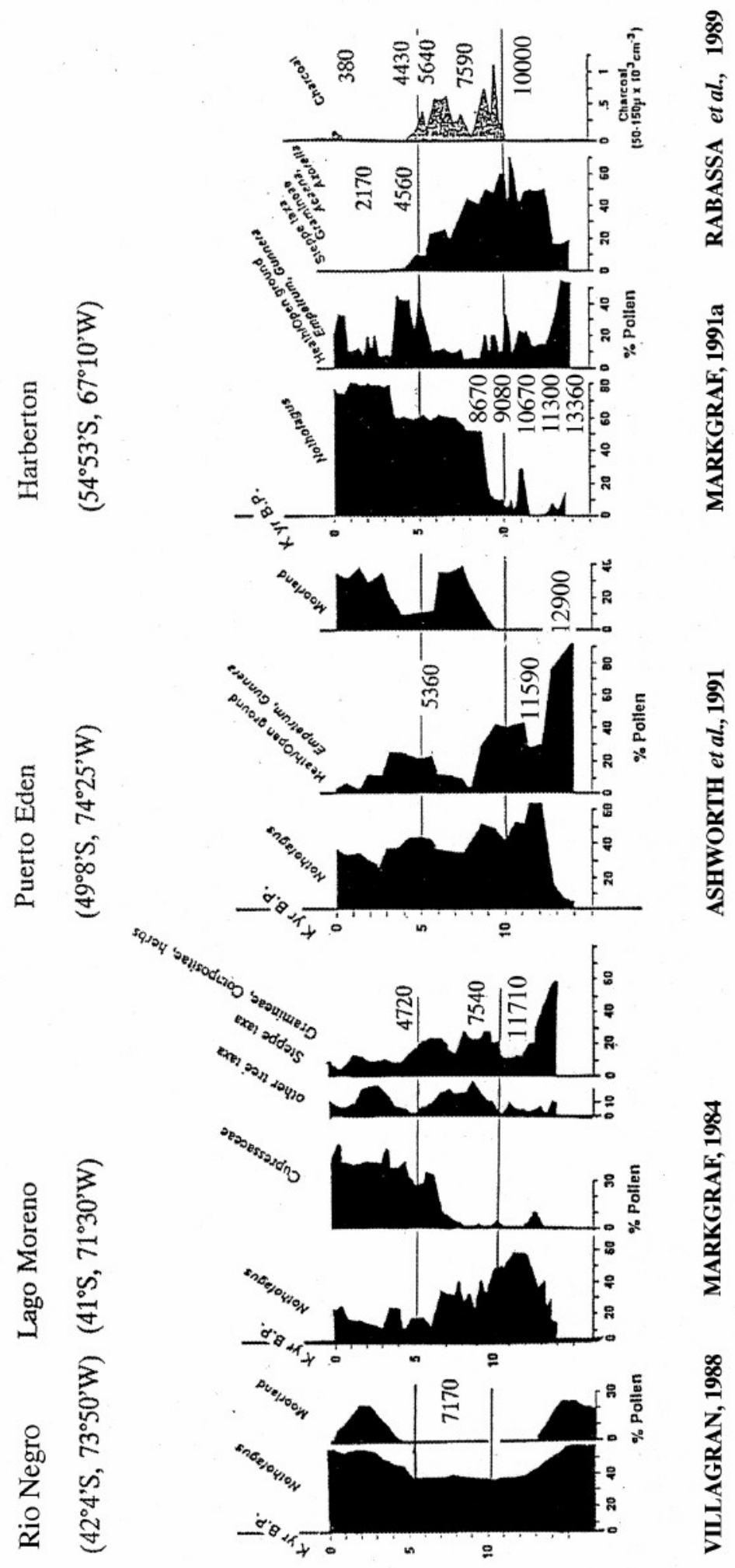

FIGURE 2 - Pollen records from southern South America showing major taxa (in percent). For site location see Fig. 1 . 
mate and hence vegetation since the last glacial maximum has been different for different latitudinal segments (figure 2) (MARKGRAF, 1991a; VILLAGRAN \& ARMESTO, 1993). This has been interpreted to relate to the changing strength and latitudinal position of the westerly stormtracks (MARKGRAF, 1989; MARKGRAF et al., 1992).

During full-glacial times, between latitudes $40^{\circ}$ and $41^{\circ} \mathrm{S}$, a $50 \%$ decrease in precipitation, relative to today, is suggested by the expansion of Nothofagus woodland to the west of the Andes (Caunahue, MARKGRAF, 1991b; Puerto Octay, MORENO, 1993) and by the replacement of forest to the east of the Andes by steppe and steppe-scrub (Lago Morenito, figure 2). In contrast to this, just to the south in the latitudinal zone between $41^{\circ}$ and $43^{\circ} \mathrm{S}$, relatively closed Nothofagus dombeyi forests expanded and moorland vegetation covered the wetlands that are now Sphagnum bogs (e.g. Rio Negro, VILLAGRAN, 1988, figure 2). This implies annual precipitation similar to modern conditions, but far greater windiness than is seen today. These conditions are comparable to the present day environment found over $5^{\circ}$ poleward.

South of latitude $45^{\circ} \mathrm{S}$ (Puerto Eden, Harberton, figure 2; see also Taitao Peninsula, LUMLEY \& SWITSUR, 1993), the initial vegetation after deglaciation (and probably also during full-glacial times) was Empetrum heath, with other taxa characteristic of open ground conditions. This vegetation resembles biota found today on pro-glacial outwash plains, or on windy basalt plateaus east of the Andes where freezing temperatures occur throughout the year and precipitation is less than $300 \mathrm{~mm}$ annually. Modern precipitation at $45^{\circ} \mathrm{S}$ is over $5000 \mathrm{~mm}$ mean annual. The full glacial vegetation suggests an environment which experienced less than $10 \%$ of the modern precipitation.

From these records it appears that climates during and shortly after deglaciation must have been substantially colder, windier, and drier than today throughout Patagonia, east and west of the Andes, with the exception of a narrow belt between latitudes $41^{\circ}$ and $43^{\circ} \mathrm{S}$ (MARKGRAF, 1991a; MARKGRAF et al., 1992; VILLAGRAN \& ARMESTO, 1993).

The development of modern forest vegetation south of $50^{\circ} \mathrm{S}$ lagged behind the zone to the north. Between latitudes $40^{\circ}$ and $50^{\circ} \mathrm{S}$, forests comparable to the modern types began to develop around 12500 years B.P. both east and west of the Andes. This implies that throughout this latitudinal stretch precipitation levels were over $2000 \mathrm{~mm}$ annually, comparable to today. Temperatures also increased to modern levels.
South of $50^{\circ} \mathrm{S}$, however, forests did not develop until after 9000 years B.P. This suggests that effective moisture remained low well into the early Holocene. Maximum moisture during the early Holocene (9000 and 6000 years B.P.) was restricted to the zone between latitudes $45^{\circ}$ and $50^{\circ} \mathrm{S}$, whereas latitudes north and south of this zone were dry relative to today. Only during the late Holocene, after about 5000 years B.P., did conditions become wetter along the whole southern part of South America. This reflects on one hand the onset of today's large seasonal shifts of stormtracks, poleward in summer and equatorward in winter, and on the other hand the influence, especially at the lower latitudes, of the El Niño/Southern Oscillation.

\subsection{Fire history}

All records from Patagonia analyzed to date for charcoal are from peat cores that have also been analyzed for pollen (figure 3 ). Charcoal abundance in these cores records regional fires as well as fires that have burnt along the bog surface itself (MARKGRAF, 1993b). In the northern region, a long paleoenvironmental record from the subtropical thornscrub-forest environments at latitude $34^{\circ} \mathrm{S}$ (Tagua Tagua, HEUSSER, 1990) shows continuously high charcoal amounts only during the last 3000 years, with few sporadic high levels during the early Holocene and prior to 30000 years B.P. Despite a substantial number of published paleoenvironmental records from the mid-latitudes between $39^{\circ}$ and $43^{\circ} \mathrm{S}$ (HEUSSER, 1966, 1981, 1984; MARKGRAF, 1991b; VILLAGRAN, 1988 , 1990) charcoal has not commonly been found. The charcoal records from this region are limited to four sites. One record spanning the full glacial to early Holocene is from the Chilean lake district (Puerto Octay, MORENO, 1993). There are two late Holocene records from near the steppe ecotone at latitude $39^{\circ} \mathrm{S}$ (Rio Malleo, HEUSSER et al., 1987) and one record from $41^{\circ} \mathrm{S}$ (M. Book, MARKGRAF, 1983). The Octay record shows high charcoal amounts between 11000 and 10000 years B.P. The Rio Malleo record shows high fire frequency throughout the last 3000 years, but no clear temporal pattern, and in M. Book only the vast European burning is recorded (VEBLEN \& MARKGRAF, 1988).

In addition to these prehistoric records, more recent records of fire history in this region have been analyzed in studies of forest dynamics during the historic period (VEBLEN \& LORENZ, 1987; VEBLEN et al., 1992). These records, along with the abundance of charcoal in the uppermost parts of sediment 


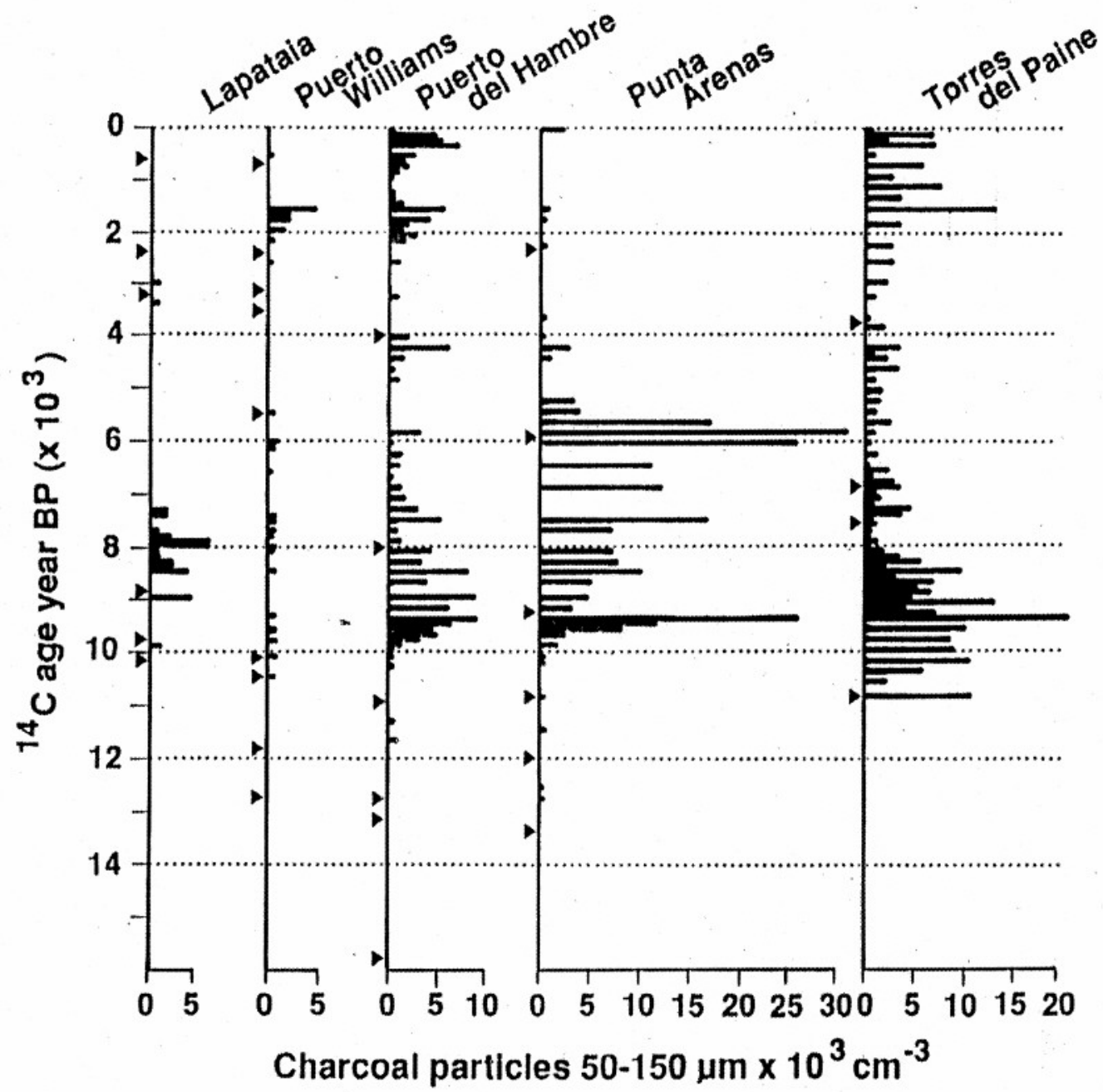

FIGURE 3 - Records of charcoal particles for the last 14000 years from peat cores from southernmost Patagonia and Tierra del Fuego (HEUSSER, 1987). For site location see Fig. 1. Triangles indicate location of radiocarbon dates in respective cores.

sections (Mallin Book, MARKGRAF, 1983) indicate that during the most recent past fires have greatly intensified. Although lightning as a cause of fires cannot be excluded - between 1938 and 1982 fourteen large-scale lightningignited fires were documented in the Nahuel Huapi National Park at latitude $41^{\circ} \mathrm{S}$ (VEBLEN \& LORENZ, 1987) - these historic fires were at least in part related to European settlement activities (VEBLEN \& MARKGRAF, 1988).

The most detailed history of past fires has been recorded for the southernmost latitudes in South America, south of latitude $50^{\circ} \mathrm{S}$ (HEUSSER, 1987). So far only one record, the Harberton core (figure 2) has been analyzed in detail for charcoal and pollen (MARKGRAF, 1993a).

In summary, for all the high latitude records, high charcoal levels are characteristic of the last 3000 years, and for the interval between (12000) 11000 and $9000(6000)$ years B. P. (figure 3). Charcoal found during the last 400 years probably relates to forest clearing and ranching activities of European colonists (VEBLEN \& MARKGRAF, 1988). The late glacial interval of high fire frequency occurs at the time of the highest levels of black carbon recorded in the Antarctic Byrd ice core (CHYLEK et al., 1992). This suggest that this earliest increase in fire was very widespread, an is most likely a response to climate change.

\subsection{Prehistoric human occupation}

The presence of Paleoindians has been widespread throughout southern South America since about 13000 yr B.P. (MASSONE, 1981; 1987; MARKGRAF, 1985; BIRD \& BIRD, 
1988; DILLEHAY, 1989; LYNCH, 1983, MENA, 1991). The initial period between 13000 and 10000 years B.P. has been named the Fishtail Point Period after the characteristic projectile points. Extant fauna as well as now extinct megafauna were hunted (including American Horse, Mastodon, Giant Groundsloth). After about 10000 years B.P. the lithic components of the tool set changed, indicating that with the megafauna's extinction shortly before 10000 years B.P. other hunting techniques were adapted.

After about 8000 years B.P. indications of a new cultural assemblage appear throughout Patagonia. These peoples utilized more specialized hunting techniques and tools, including boleadoras (stone balls for throwing) used primarily for guanaco hunting. Finally, about 2000 years ago other tool types characterized by small and finely carved projectile points became common, suggesting a focus on hunting small fauna, birds and rodents.

Shortly after that time, but only as far south as the mid-latitudes of about $40^{\circ} \mathrm{S}$, incipient agriculture began with cultivation of maize and squash. Pottery appeared simultaneously, suggesting the beginnings of permanent settlements. This was the situation in southern Chile and Argentina when, in the 16th century, the first Spanish contacts were made. The European horse and sheep were introduced, as well as illness and competition for land that ultimately all but eliminated the native population. European impact throughout Patagonia was very intense, involving extensive burning to create grazing land, even within the Andean forests, by the late 19th century (WILLIS, 1914).

Thus, for most of the period since Paleoindians were known in Patagonia, hunting and gathering have been the primary human activities and the impact on the environment was corollary. This impact may have been substantial. Eyewitness reports from early explorers and missionaries mention large-scale fires set by Indians to hunt guanacos and rheas (FONCK, 1990; COX, 1963; MUSTERS, 1871 etc.) and to clear the forest for cultivation (FURLONG, 1964). Although hunting may always have been most profitable in the more open ecotonal forests where game was more abundant and easier to hunt, such as along the steppe/forest ecotone, in river valleys, and near the upper treeline, even the western dense rainforests were at least seasonally visited (BORRERO, 1983; MENA, 1983). This implies that the Paleoindian impact through fires could well have been a widespread phenomenon in all Patagonian environments. The intensity of the Indian-set fires, however, and the regional extent probably was substantially less than the fires set deliberately by white settlers at the end of the 19th century in the mid-latitudes in Argentina (VEBLEN \& LORENZ, 1988), and in the 1930's and 1940's in southern Chile (ELIZALDE, 1967). During that time many of the forests burnt for decades. A $50 \mathrm{~cm}$ thick charcoal layer near the surface in one of the sediment sections near Bariloche (latitude $41^{\circ} \mathrm{S}$ ) documents the lenght and intensity of the burning (MARKGRAF, 1983). Extensive areas of standing burnt trees in grassland and scrub communities throughout southern Chile and Argentina are a permanent testimony to the destruction. To this date forests have not recovered from the severity of the impact, even in the National Parks where for the last 80 years burning other than lightning-caused fires were discontinued.

\section{DISCUSSION}

Regional fire extent and fire frequency in southern South America has varied markedly during the last 15000 years. Highest fire frequency and regional extent is recorded from latitudes south of $50^{\circ} \mathrm{S}$ during the late glacial between 11000 and 9000 years B.P. At that time the regional vegetation was still essentially treeless. Low water levels in lakes and bogs suggests low effective moisture, most probably with the greatest moisture stress occurring in summer. High charcoal was also recorded at one site at latitude $41^{\circ} \mathrm{S}$ for the same time interval, despite the fact that there the regional vegetation was already a dense NothofagusMyrtaceae forest, suggesting the absence of seasonal moisture stress (MORENO, 1993).

There is no simplistic explanation for such simultaneous fire occurrences in greatly different environmental settings and hence greatly different precipitation and fuel regimes. Since summer-drought conditions, commonly evoked as a cause of fires, only occurred in the southernmost areas of this region, they cannot be the ultimate cause, although drought apparently enhanced the frequency and spatial extent of fires. Instead we suggest that the fire occurrences are related to marked increase in climatic variability during the late glacial interval, independent of the amount of precipitation or the degree of moisture stress. Climatic variability has been recorded for that interval in ice records from both Antarctica (Vostoc, JOUZEL, et al., 1987) and Greenland (TAY- 
LOR et al., 1993; GROOTES et al., 1993); in terrestrial records globally, using pollen (e.g. PONS et al., 1992); and in marine records (e.g. LEHMAN \& KEIGWIN, 1992).

This climatic variability is also documented locally for southern South America. Using deuterium analyses in one of our peat records (Harberton, MARKGRAF \& KENNY, in press), interpreted to reflect temperature, repeated high amplitude fluctations occurred between 12500 and 9000 B.P. Temperature in these high southern latitudes is linked to circum-Antarctic sea ice extent, which in turn influences the latitudinal position of the stormtracks. Thus, cold conditions would imply greatly extended sea-ice and equatorward position of the stormtracks, resulting in local dryness in the southernmost latitudes. For warm conditions, reduced sea-ice extent would allow a more southerly position of the stormtracks and more precipitation.

From recent studies on fire occurrences, including analysis of the El Niño/Southern Oscillation (ENSO) anomaly it has been shown that it is the alternation between wet and dry intervals that causes high fire frequencies (SWETNAM \& BETANCOURT, 1992). The onset of the ENSO variability is suggested to have occurred around 5000 B.P. (McGLONE $e t$ al., 1992). This suggests that the late Holocene increase in fire frequency, this time throughout southern South America is also due to climate variability, in this case to the onset of ENSO.

Because lightning storms are rare at high latitudes in modern climatic conditions, these have not been considered an important trigger for fires. Satellite imagery from the U.S. Air Force Defense Meteorological Satellite Program (unpublished data) has documented lightning in the Tierra del Fuego region, although far less frequent than at mid-latitudes. Although lighting is not a significant factor influencing high latitude fire frequency today, climatic circumstances may have been sufficiently different during the late glacial and early Holocene that lightning did play an important role in determining fire frequency.

With respect to the relative importance of humans in prehistoric fires (sensu HEUSSER, 1987), at this stage there does not seem to be a clear answer. Humans have been present throughout the period of the paleorecord, including the period prior to the increase in fire frequency. As historically documented, fire was used for hunting practices, primarily in the steppe regions, and could have escaped into the forest regions. However, without receptive climate conditions, man-set fires probably could not have resulted in widespread burning, lasting thousand years or more as shown in the paleoenvironmental records.

Except for the most recent period of European colonization, there appears to be no clear relationship between fire frequency and cultural phases. The archaeological evidence shows a marked change in the lithic tool kit from the time of earliest human occupation to the period after megafaunal extinction. This change in tool kit and available game animals suggests changes in hunting strategy which very likely included changes in the use of fire as a hunting tool. Yet the interval of highest fire frequency bridges the period before and after megafaunal extinction. High fire frequency during the late Holocene, on the other hand, falls into times when the primary game, small animals and birds, did not require fire as part of the hunting strategy. This lack of temporal correlation between human activity and changes in fire frequency suggests that the influence of humans has not been a major control on fire regime. While humans may have been the initiators of fire in many instances, the determining factor in the spacial extent and intensity of burning has been climatic conditions. Among the various aspects of climate which may predispose vegetation communities either to resilience and resistance or vulnerability to fire, frequency and amplitude of climatic variability is most significant.

\section{BIBLIOGRAPHY}

ASHWORTH, A.C.; MARKGRAF, V. \& VILLAGRAN, C. 1991. Late Quaternary climatic history of the Chilean Channels based on fossil pollen and beetle analysis, with an analysis of the modern vegetation and pollen rain. Journal of Quaternary Science, 6:279-291.

AUER, V.1974. The isorythmicity subsequent to the Fuego-Patagonian and Fennoscandian ocean level transgressions and regressions of the latest glaciation. Annales Academiae Scientiarum Fennicae, AIII, 100:1-94.

BIRD, J.B. \& BIRD, M. 1988 Travels and Archaeology in South Chile, University of Iowa Press. 246pp.

BORRERO, L.A. 1983. On cultural adaptation in the subantarctic zone. Current Anthropology, 24:241-242. 
CHYLEK P.; JOHNSON, B. \& WU, H. 1992. Black carbon concentration in Byrd Station ice core: from 13000 to 700 years before present. Annales Geophysicae, 10:625-629.

CLARK, R.L. 1982. Point count estimation of charcoal in pollen preparations and thin sections of sediments. Pollen et Spores, 24:523-535.

CLARK, J.S. 1988. Particle Motion and the Theory of Charcoal Analysis: Source Area, Transport, Deposition, and Sampling. Quaternary Research, 30:67-80.

1989. Effects of Long-term Water Balances on Fire Regime, Northwestern Minnesota. Journal of Ecology, 77:989-1004

CLARK, J. 1992. Ecosystem sensitivity to climate change and complex responses. In Global Climate Change and Life on Earth (R. Wyman ed.), Chapman and Hall, New York, New York.

COX, G. 1963. Viajes a las regiones septentrionales de Patagonia 1862-1863. Anales de la Universidad de Chile, 23:3-239 and 437-509.

CWYNAR, L.C. 1978. Recent history of fire and vegetation from laminated sediment of Greenleaf Lake, Algonquin Park, Ontario. Canadian Journal of Botany, 56:10-21.

DODSON, J.R. 1988. The perspective of pollen records to study response, competition and resilience in vegetation on Barrington Tops, Australia. Progress in Physical Geography, 12(2): 183-208.

DILLEHAY, T.D. 1989. A Late Pleistocene Settlement in Chile. Paleoenvironment and Site Context, Vol. 1. Smithsonian Institution Press, Washington, D.C.

ELIZALDE, R. 1967. La Sobrevivencia de Chile. Ministerio de Agricultura, Servicio Agricola y Ganadero, Santiago.

ERIKSEN, W. 1975. Disruptions in the Ecosystems of the Steppe and Forest Regions of Patagonia by Climate and Man. Applied Sciences and Development, 6.

FAEGRI, K. \& IVERSEN, J. 1989. Textbook of Pollen Analysis. IV edition. Wiley: New York.

FONCK, F. 1900. Viajes de Fray Francisco Menendez a Nahuelhuapi. Valpariso: C.F. Niemeyer.
FURLONG, C.G. 1964. Nicolas Mascardi, S.J. y su carta-relacion (1970). Buenos Aires: Editorial Universitaria Kennedy.

GILL, A.M.; GROVES, R.A. \& NOBLE, I.R. (eds.) 1981. Fire and Astralian Biota. Australian Academy of Science, Canberra.

GILL, A.M. 1975. Fire and the Australian flora: A review. Australian Flora, 38:4-25.

GREEN, D. 1983. The ecological interpretation of fine resolution pollen records. New Phytologist, 94:459-477.

GREEN, D. \& DOLMAN, G.S. 1988. Fine resolution pollen analysis. Journal of Biogeography, 15:685-701.

GREEN, D.: SINGH G.; POLACH, H.; MOSS, D.; BANKS, J \& GEISSLER, E.A. 1988. A fine-resolution palaeoecology and palaeoclimatology from south-eastern Australia. Journal of Ecology, 76:790806.

GRIMM, E. C. 1984. Fire and Other Factors Controlling the Big Woods Vegetation of Minnesota in the Mid-Nineteenth Century. Ecological Monographs, 54:291-311.

GROOTES, P.M.; STUIVER, M.; WHITE, J.W.C.; JOHNSON, S. \& JOUZEL, J. 1993. Comparison of oxygen isotope records from the GISP2 and GRIP Greenland ice cores. Nature, 366:552-554.

HEUSSER, C.J. 1966. Late Pleistocene pollen diagrams from the Province of Llanquihue, southern Chile. Proceedings American Philosophical Society, 110:269-305.

1981. Palynology of the last interglacial-glacial cycle in midlatitudes of southern Chile. Quaternary Research, $16: 293-321$.

1984. Late-glacial - Holocene climate of the lake district of Chile. Quaternary Research, 22:77-90.

1987. Fire History of FuegoPatagonia. Quaternary of South America and Antarctic Penisula, 5:93-110.

1990. Ice age vegetation and climate of subtropical Chile. Palaeogeography, Palaeoclimatology, Palaeoecology, 80:107-127.

HEUSSER, C.J. HEUSSER, L.; HAUSSER, A. 1989. A 12000 Year B.P. Tephra Layer at Bahia Inutil (Tierra del Fuego, Chile) Anales Instituto de la Patagonia, 19:39-49. 
HEUSSER, C.J. \& FLINT, R.F. 1977. Quaternary glaciations and environments of northern Isla Chiloé, Chile. Geology, 5:305-308.

HEUSSER, C.J. \& RABASSA, J. 1987. Cold climatic episode of Younger Dryas age in Tierra del Fuego. Nature, 328:609-611.

HEUSSER, C.J.; RABASSA, J.; BRANDANI, A. \& STUCKENRATH, R. 1987. Vegetacion del Holoceno Tardio de la Region Andina con Araucaria de la Provincia del Neuquem, Argentina. Actas, VII Simposio Argentino de Paleobotanica y Palinologia

JACOBSON, G. Jr. \& BRADSHAW, R.H.W. 1981. The selection of sites for paleoenvironmental studies. Quaternary Research, 16:80-96.

JOHNSON, E.A. 1979. Fire recurrence in the subarctic and its implications for vegetation composition. Canadian Journal of Botany, 57:1374-1379.

JOUZEL. J.; LORIUS, C.; MERLIVAT, L. \& PETIT, J.R. 1987. Abrupt climatic change: the Antarctica ice record during the late Pleistocene. In: Abrupt Climatic Change: Evidence and Implications (W.H. Berger and L.D. Labeyrie, eds.). Reidel, Dordrecht, pp. 235

KEMP, E.M. 1981. Pre-Quaternary fire in Australia. In: A.M. Groves, R.A. Groves and I.R. Noble (eds.). Fire and Australian Biota, Australian Academy of Science, Canberra.

KERSHAW, A.P. 1986. Climatic change and Aboriginal burning in north-east Australia during the last two glacial/interglacial cycles. Nature, Vol. 322:47-49.

LEHMAN, S.J. \& KEIGWIN, L.D. 1992. Sudden changes in North Atlantic circulation during the last deglaciation. Nature, 356:757-762.

LUMLEY, S.H. 1992. Palynological evidence for a late Holocene decline in Pilgerodendron uviferum on the Taitao Peninsula, Chile. Program and Abstracts, 8th Internatl. Palynological Congress, Aix-en-Provence, 1992; p. 168.

LUMLEY, S.H. \& SWITSUR, R. 1993. Late Quaternary chronology of the Taitao Peninsula, southern Chile, Journal Quaternary Science, 8:161-165.

LYNCH, T.F. 1983. The Paleo-Indians. Ancient South Americans (Jennings, J.D., ed), Freeman, San Francisco.
MARKGRAF, V. 1983. Late and postglacial vegetational and paleoclimatic changes in subantarctic, temperate, and arid environments in Argentina. Palynology, 7:43-63.

1984. Late Pleistocene and Holocene vegetation history of Temperate Argentina: Lago Morenito, Bariloche, Dissertationes Botanicae, 72:235-254.

1985. Late Pleistocene faunal extinction in southern Patagonia. Science, 228:1110-1112.

1989a. Late Pleistocene/ Holocene paleoclimates from subantarctic Nothofagus forest. Quaternary Research, 28:119-129.

1989b. Reply to Heusser's "Southern Westerlies during the last glacial maximum." Quaternary Research, 31:426-432.

1991a. Late Pleistocene environmental and climatic evolution in southern South America. Bamberger Geographische Schriften, 11:271-281.

1991b. Younger Dryas in southern South America. Boreas, 20:63-69. 1993a. Paleoenvironments and Paleoclimates in Tierra del Fuego and southernmost Patagonia, South America. Palaeogeography, Palaeoclimatology, Palaeoecology. 102:53-68.

1993b. Younger Dryas in southern South America - an update. Quaternary Science Review.

MARKGRAF, V.; DODSON, J.R.; KERSHAW, P.A.; McGLONE, M. \& NICHOLLS, N. 1992. Evolution of late Pleistocene and Holocene climates in circum South Pacific land areas. Climate Dynamics, 6:193-211.

MARKGRAF, V. \& KENNY, R. (in press). Character of rapid vegetation and climate change during the late-glacial in southernmost South America. Proceedings NATO Workshop on Past and Future Rapid Environmental Changes. Springer Verlag.

MASSONE, M.M. 1981. Arqueologia de la Region Volcanica de Pali-Aike (Patagonia Meridionale Chilena). Anales del Instituto de La Patagonia, Vol. 12.

1987. Los cazadores paleo indios de Tres Arroyos (Tierra del Fuego). Anales Instituto de la Patagonia, 17:47-60. 
McGLONE, M.S.; KERSHAW, A.P. \& MARKGRAF, V. 1992. El Niño/ Southern Ocillation climatic variability in Australasian and South American paleoenvironmental records. In: Diaz, H.F. and Markgraf, V. (eds). El Ninõ: Historical and Paleoclimatic Aspects of the Southern Oscillation. Cambridge University Press, 435-462.

MENA, F.L. 1983. Excavaciones Arqueologicas en Cueva Las Guanacas (RI-16) XI Aisen Region Anales del Instituto de La Patagonia, 14.

1991. Cazadores recolectores en el area Patagonica y tierras bajas aledañas (Holoceno medio y tardio). Revista de Arqueología Americana, 4:131-163. (Instituto Panamericano de Geografía e Historia).

MILLER, G.H. 1992. Drought in the Australian Outback: Anthropogenic impact on regional climate. American Geophysical Union, Abstracts, 1992 fall meeting, San Francisco, p. 104.

MORENO, P.I. 1993. Vegetation and climate near Lago Llanquihue in the Chilean Lake District between 20200-9500 yr B.P. Abstracts International Workshop "The Quaternuy of Chile", Santiago 1-9 November, 1993.

MUSTERS, G.C. 1871. At home with the Patagonians: a year's wanderings over untrodden ground from the straits of Magellan to the Rio Negro. London, J. Murray.

PICKETT, S.T.A.; KOLASA, J.; ARMESTO, J.J. \& COLLINS, S.L. 1989. The ecological concept of disturbance and its expression at various hierachical levels. OIKOS, 55:129-136.

PATTERSON III, W.A. \& SASSAMAN, K.E. 1988. Indian fires in the prehistory of New England. In Holocene Human Ecology in Northeastern North America (G.P. Nicholas, ed.) Plenum, 107-135.

PONS, A.; GUIOT, J.; BEAULIEU, J.L. \& REILLE, M. 1992. Recent contributions to the climatology of the last glacial interglacial cycle based on French pollen sequences. Quaternary Science Review, 11:439-448.

PRENTICE, I.C. 1985. Pollen representation, source area, and basin size: Toward a unified theory of pollen analysis. Quaternary Research, 23:76-86.
RABASSA, J.; HEUSSER, C.J. \& RUTTER, N. 1991. Late-glacial and Holocene of Argentine Tierra del Fuego. Quaternary of South America and Antarctic Peninsula, 7:327-352.

RECHER, H.F. \& CHRISTENSEN, P.E. 1981. Fire and the evolution of the Australian biota. In: A.M. Groves, R.A. Groves and I.R. Noble (eds.) Fire and Australian Biota, Australian Academy of Science, Canberra.

SCHNEIDER, S. 1976. The Genesis Strategy Climate and Global Survival. Plenum Press: New York.

SINGH, G.; KERSHAW, A.P. \& CLARK, R. 1981. Quaternary vegetation and fire history in Australia. In: A.M. Groves, R.A. Groves and I.R. Noble (eds.). Fire and Australian Biota Autralian Academy of Science, Canberra.

STERN. C.R. 1990. Tephrachronology of southernmost Patagonia. National Geographic Society Research, 6:110-126.

1992. Implications of Tephrochronology for the Age of the Human Occupation of Tierra del Fuego, Research and Exploration. 8:230-231.

SWETNAM, T.W. \& BETANCOURT, J.L. 1992. Temporal patterns of El Ninõ/Southern Oscillation - widfire teleconnections in the southwestern United States. In: El Nino, Historical and Paleoclimatic Aspects of the Southern Oscillation (H.F. Diaz and V. Markgraf, eds.). Cambridge University Press, Cambridge, p. 259-270.

TAYLOR, K.C.; HAMMER, C.U.; ALLEY, R.B.; CLAUSEN, H.B.; DAHLJENSEN; D. GOW, A.J.; GUNDESTRUP, N.S.; KIPFSTUHL, J.; MOORE, J.C. \& WADDINGTON, E.D. 1993. Electrical conductivity measurements from the GISP2 and GRIP Greenland ice cores. Nature, 366:549-552.

VEBLEN. T.T. \& LORENZ, D.C. 1987. Postfire stand development of AstrocedrusNothofagus forests is northern Patagonia, Vegetatio, 71:113-126.

1988. Recent Vegetation Changes along the Forest/Steppe Ecotone of Northern Patagonia. Annals of the Association of American Geographers, 78(1):93-111.

VEBLEN, T.T. \& MARKGRAF, V. 1988. Steppe Expansion in Patagonia. Quaternary Research, 30:331-338. 
VEBLEN, T.T.; KITZBERGER, T \& LARA, A. 1992. Disturbance and forest dynamics along a transect from Andean rain forest to Patagonian shrubland. Journal of Vegetation Science, 3:507-520.

VILLAGRAN, C. 1988. Expansion of Magellanic moorland during the late Pleistocene: palynological evidence from northern Isla de Chiloé, Chile. Quaternary Research, 30:304-314. 1990. Glacial climates and their effects on the history of the vegetation of Chile: A synthesis based on palynological evidence from Isla de Chiloé. Review of Palaeobotany and Palynology, 65:17-24.

VILLAGRAN, C. \& ARMESTO, J.J. 1993. Full-and late glacial paleoenvironmental scenarios for the west coast of southern South America. In. Earth System Responses to Global Change: Contrasts between North and South America, (H.A. Mooney, E.R. Fuentes, and B.I. Kronberg, eds.) Academic Press. pp. 195-207.

WILLIS, B. 1914. Northern Patagonia, Comisión de Estudios Hidrológicos, Ministry of Public Works, Buenos Aires, Argentina.

WRIGHT, Jr., H.E. 1981. The Role of Fire in Land/Water Interactions. Fire Regimes and Ecosystem Properties (H.A. Mooney, J.M. Bunnicksen, N.L. Christensen, J. e Lotan and W.A. Reiners, eds.) U.S. Forest Service, General Technical Report WO-26, pp. 421-444..

Address of the authors:

Vera Markgraf and Lysanna Anderson - Institute of Artic and Alpine Research-1560, 30th Street - Campus Box 450 Boulder, Colorado 00309-0450 - USA. 